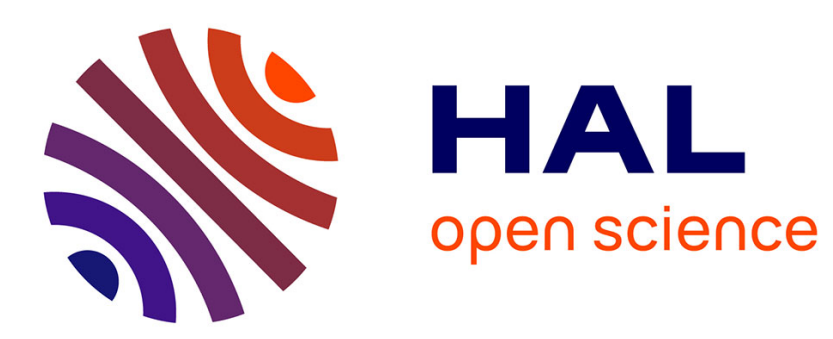

\title{
Allying beyond social divides: An introduction to contentious politics and coalitions in the Middle East and North Africa
}

Yasmine Berriane, Marie Duboc

\section{- To cite this version:}

Yasmine Berriane, Marie Duboc. Allying beyond social divides: An introduction to contentious politics and coalitions in the Middle East and North Africa. Mediterranean Politics, 2019, 24 (4), pp.399-419. 10.1080/13629395.2019.1639022 . hal-02313891

\section{HAL Id: hal-02313891 \\ https://hal.science/hal-02313891}

Submitted on 11 Oct 2019

HAL is a multi-disciplinary open access archive for the deposit and dissemination of scientific research documents, whether they are published or not. The documents may come from teaching and research institutions in France or abroad, or from public or private research centers.
L'archive ouverte pluridisciplinaire HAL, est destinée au dépôt et à la diffusion de documents scientifiques de niveau recherche, publiés ou non, émanant des établissements d'enseignement et de recherche français ou étrangers, des laboratoires publics ou privés. 
Preprint Version, published in Mediterranean Politics, Vol. 24, Nr.4, 2019, pp.399-419.

Access here: https://www.tandfonline.com/doi/full/10.1080/13629395.2019.1639022

\section{Allying Beyond Social Divides: An Introduction to Contentious Politics and Coalitions in the Middle East and North Africa}

Yasmine Berriane and Marie Duboc

Coalitions of actors that have traditionally not been allies but who join forces to achieve a common goal have been a recurrent factor in contentious politics in North Africa and the Middle East, from anticolonial movements to post-independence mobilizations. Bridging social, regional, and ideological divides, they have developed in various social spaces such as anti-regime opposition groups, anti-globalization networks, and movements claiming economic rights, the equal distribution of resources, and social justice. Within such alliances, 'strange bedfellows' (Clark, 2010, p. 101) have joined forces: Islamists with leftists, urban with rural protesters, lawyers with peasants, armed forces with opposition movements, workers with students, marginalised populations with established elites.

Coalitions are nothing new in the Middle East: the early struggles against European colonization, including the Arab revolt of 1915, the 1919 insurrection in Egypt and the Iraqi uprising of 1920, offer many examples of coalitions that brought together broad constituencies. More recently, however, such coalitions have especially attracted the attention of researchers because processes of networking that started long before 2011 have greatly contributed to the broad-based uprisings that shook the region from 20102011 (Abdelrahman, 2011; Beinin, 2014). Moreover, the diversity that characterized the actors involved in the 2011 uprisings in the Middle East played a vital role in bringing about regime change while at the same time contributing to these coalitions' inability to endure afterwards. Lacking internal coherence, the coalitions that were crucial to the success of the Arab revolts proved unsustainable in the longer term (Goldstone, 2011; Durac, 2015). 
Such processes of coalition-building across social, regional, and ideological divides are not specific to the Arab region: they are also a striking feature of contemporary social movements in other parts of the world. In the current context of increasing inequalities and precarity, collaborations across differences have been depicted as a condition of 'precarious survival' (Tsing, 2015). Coalition-building has been theorized as an alternative to identity politics (Butler, 2016), and 'multipartner coalitions' based on 'inclusive politics that can bridge the many divisions in our society' have been portrayed as 'the political challenge of the day' (Rose, 2000, pp. 5-9). Indeed, in different parts of the world 'political and economic changes over the past decades have been met with a renewed emphasis from both activists and scholars on the importance of social movement coalitions' (Van Dyke \& McCammon, 2010, p. xi). This interest has been reinforced by the intensified development of instruments of communication and transportation that enable the formation of transnational and transregional coalitions irrespective of spatial distance.

Studies that have analysed coalition-building within authoritarian and constrained settings such as those that predominate in the Middle East and North Africa (or MENA region) have focused on alliances that bridge ideological divides, seeking to identify the factors that favour their success. Although not always specifically addressing the issue of coalition-building, recent research produced on the uprisings that developed in the region since 2010-2011 offers, however, insightful examples of alliances that cross other divides, based on socio-political and regional divisions for instance. Building upon these insights, new key questions specifically related to the making of coalitions in the MENA region emerge. How do coalitions form across social divides based on class, gender, or generation? How do coalitions of actors and organizations with different repertoires, social capital, and interests come into being? How are these differences bridged and how is a minimal degree of unity and coherence built? What kinds of tensions and power struggles emerge within such coalitions and how are they negotiated? What impact has the collaboration of such varied actors on the way contentious issues are articulated and addressed by the state? And in what sense are such encounter-based collaborations transformative?

Focusing on political developments in the MENA region, this special issue explores coalition-building, privileging processual, relational, and intersectional approaches that take into account these questions, and the manifold (micro-)transformations that emerge 
out of the 'coalition moments' when actors or groups come together to achieve a specific goal. More particularly, we address three main gaps in the literature on coalitions in the MENA region.

First, we argue that to better understand the making - and the unmaking - of coalitions in the region it is essential to go beyond ideological divides. We argue for the need to extend the analysis to other divides based on gender, class, ethnicity, generation, and even professional hierarchies. Second, we go beyond the failure-success nexus that has dominated the study of coalitions in the MENA region; in other words, beyond analyses that focus mainly on identifying the factors that led to a coalition's success or failure in achieving its objectives. Through scale shifts and processes of diffusion and construction of common goals, meanings and references, coalitions can lead to transformations that affect relations with political authorities, ideological learnings, and understandings of the notion of right. Third, rather than analysing coalitions and social divides as two opposite processes our aim is to show that studying the alliance of social groups and movements goes hand in hand with exploring processes of differentiation and categorization. Coalitions can also contribute to social divides by reinforcing differences between categories and producing new ones. It is therefore important to situate the construction of coalitions and their social and political implications within a long-term perspective that takes into consideration processes that precede and follow the 'coalition moment'.

In this introduction we first clarify our conceptual understanding of the notion of coalition and how we link it to other concepts, such as networks and social movements. We then present the main trends that characterize the literature on coalitions in the MENA region, before moving in more detail to this special issue's main contributions to the study of alliances and change.

\section{Networks, coalitions and social movements: conceptual clarifications}

According to David S. Meyer and Nancy Whittier (1994, p.290), 'Coalitions are structuring mechanisms that bring a broad spectrum of otherwise distinct organizations into contact, spreading interpretive frames, organizational structures, political analysis, and tactics'. Starting from this very broad definition, in this first section we clarify our working definitions and highlight the theoretical gaps that we address in this issue. In 
order to better define what we mean by coalition, we situate the term in relation to two other key notions: the network and the social movement.

We are mainly interested in coalitions that have come together in relation to the emergence of protest actions or a social movement, defined by Sidney Tarrow and Charles Tilly (2007, p.8) as 'a sustained campaign of claim-making, using repeated performances that advertise the claim, based on organizations, networks, traditions and solidarities that sustain these activities'. Forging alliances is a core activity of social movements: it helps broaden support for the movement and diversifies its constituents. Such alliances can take different shapes, ranging from a simple partnership between two groups to a complex network. They can be formal, with an umbrella organization; informal, limited to a single common project; or the basis for long-lasting collaborations (Van Dyke \& McCammon, 2010, pp. xiv-xv).

The formation, organizational structure and goals of such alliances indicate that coalitions and networks are interrelated processes. Networks have long been recognized as a key aspect of social movements and are a focus of social movement studies (Diani \& McAdam, 2003). The conventional, vague definition of networks sees them 'as sets of nodes, linked by some form of relationship, and delimited by some specific criteria' (Diani \& McAdam, 2003, p. 2) to accommodate the wide range of actors involved in social movements.

One approach to the study of networks considers them instrumental in facilitating the mobilization and recruitment of social movement actors. Another strand of research has shown that collective action can lead to the creation of networks (Tarrow, 2011, p. 139). In other words, networks are not just an opportunity for people to mobilize: they are indicative of the interactions between people and organizations (Diani, 2004, p. 339). From this perspective, networks matter to social movements not simply because they facilitate recruitment and participation but also because they contribute to influencing social structures through collective action.

Networks are also crucial to the making of coalitions. Among the factors that favour the emergence of coalitions, authors have highlighted the role of social ties that allow the exchange of information and resources between organizations and actors. To clarify the definition of the term 'coalition' it helps to consider the pivotal role that networks and 
pre-existing social ties play in shaping the various forms of cooperation and alliance between actors and organizations. Diani and MacAdam's (2003, p.10) distinction between 'coalition networks' and 'movement networks' clarifies the characteristics of coalitions by taking into account the nature of interactions between individual actors or organizations. Movement networks involve a sense of collective identity and commitment to a shared cause, and are marked by 'sustained interactions between different political organizations, which go beyond a single-issue campaign to draw on, and reproduce, distinctive collective identities' (ibid, p. 304).

In contrast, coalition networks rely on short-lived and temporary instrumental alliances (Lemieux, 1997). They 'take a purely contingent and instrumental nature' (Diani \& Bison 2004, p. 285) and involve forms of interactions between different groups and individuals whose loyalty most often remains centred on distinct organizations. The ad hoc nature of interactions between coalition members means that they join forces during atomized, isolated campaigns or events. In the absence of sustained exchanges of resources in pursuit of common goals, coalition networks fall short of creating a common collective identity, an essential element that distinguishes them from social movement processes: 'It is the definition of a shared identity which qualifies a movement network vis-à-vis a coalition network, and draws its boundaries' (Diani \& McAdam, 2003, p. 10).

By situating coalitions outside the realm of social movements, this definition helps to analytically differentiate networks, coalitions, and social movements. Empirically, it also enables us to depart from approaches centred on evaluating the outcomes of coalitions based solely on their capacity to establish durable movements. As the contributions in this volume show, while 'coalition moments' are limited in time and space they are far from irrelevant social phenomena. They deserve to be studied in their own right as indicative of collaboration between actors.

Three core characteristics serve as a starting point in our understanding and study of coalitions. First, their temporality: the lifetime of such alliances is by definition limited and short. This turns existing analyses of coalitions, which primarily focus on evaluating outcomes and determining why coalitions fail to become more sustainable political projects beyond single events or campaigns, on their head. What counts as 'sustainable' or 'short-term', especially in contexts of political closure that characterize authoritarian regimes, remains open to debate and requires contextualization. Diani and McAdam's 
(ibid) account neglects such alliances' ability to create long-lasting organizational and/or ideational change. By contrast, the contributions to this volume show that by seeing the ebb and flow of coalitions as ordinary rather than anomalous it is possible to shift the focus to what they do and how they influence social structures, shape norms, representations and discourses, and challenge the boundaries between coalitions and social movements.

The second characteristic refers to the interactions between the different groups and individuals that make up a coalition, and in particular to the issue of conflict. Internal differences are a core feature of coalitions, especially in cases where groups with different cultures, practices, ideological perspectives, identities, and goals join forces. Such differences can inhibit the formation of coalitions, and coalition-building processes therefore often go hand in hand with the formulation of common goals, the identification of congruent ideologies and identities, and the development of common frames (Van Dyke and McCamon, 2010, pp. xii-xvi; Cornfield \& McCammon, 2010, p. 80). But the terms 'alliance' and 'coalition' also imply that there is no intention, at least initially, to merge these different groups and actors under a single movement (Rucht, 2004, p. 203): keeping their individual distinctiveness is therefore also critical to the viability of the groups and actors that make up such alliances (Abdelrahman, 2009). Internal differences are further shaped by power relations and internal inequalities; for example, within an alliance, better-connected organizations have more power and resources in determining the coalition's strategies. Ideological differences may also inhibit the formation of a coalition. In fact, 'once a coalition is actually created, tensions may arise among member organizations with different amounts of resources, different political emphases, and different styles of organization. Such tensions are costly in terms of time and energy' (Roth, 2010, p.103).

Hence competition and conflict are inevitable features of coalitions. Rather than evaluate the impact of these tensions on the viability or even the success of coalitions, the contributions in this issue take a close look at conflicts within coalitions to understand where these struggles and divides originate and how they are overcome and reinvented during the formation of the coalition. Sharing the same goal is not enough: "coalition work' is necessary (Staggenborg, 1986; Shaffer, 2000). 
Studying how differences and social divides are bridged within coalitions is particularly relevant when it comes to the MENA region, which is often depicted as a segmented and divided mosaic in which primordial identities obstruct political change. ${ }^{1}$ These divides are the result of complex historical processes in which political regimes have played a crucial role (Haddad, 2014; Davis 2008; Makdisi, 2000). Social and political divides are, for instance, part and parcel of 'divide and rule' strategies designed to hinder the capacity of different groups to work together or join forces against the regime; the development of corporatism is illustrative of such strategies (see the contribution on Iran by Zep Kalb in this issue). Some forms of action are enabled or contained, while others are excluded. Divisions between categories such as public and private, insiders and opponents, 'economic' and 'political' (Abdelrahman, 2012; Bogaert, 2015) are enforced. Such divisions shape the ways in which state institutions operate and interact with protesters, and the possibilities for social movements to coordinate their actions. This was the case, for example, between supporters of political Islam and leftist groups in Egypt in the 1970s, and between the Sunni and Shi'a populations in Bahrain in the 1990s and again in 2011-12. Divisions can also emerge in reaction to policy, as in Libya following the collapse of the Gaddafi regime when local elites' confrontational strategies at the national level triggered local divisions, threatening local unity (Lacher, 2016).

Under such circumstances, when opposition groups seek to challenge the status quo other groups are likely to dissociate themselves from the former's actions and political agendas in order to appear less threatening in the eyes of decision-makers. Set against this background, coalitions that manage to bridge such divisions even temporarily take on a whole new meaning: they become ways of challenging the incumbent regime by reinventing and reshuffling social divides. For instance in Bahrain, despite the sectarian logic of the ruling Al-Khalifa regime, petitions in 1992-94 calling for meaningful political representation and constitutional reform gathered a wide range of groups and movements from workers to business representatives, liberals, Shi' as and Sunnis, and culminated in mass demonstrations that were heavily repressed but managed to sustain a movement until concessions were won in 1999 (Chalcraft, 2016, pp.498-501).Thus, studying the way in which divisions are bridged also informs us more generally about alternative strategies of dissent and about changing power hierarchies.

\footnotetext{
${ }^{1}$ See Barakat (1993) for a critic of the mosaic model.
} 
The third feature we address in this issue is change. Coalitions relate to other prominent notions of social movements such as the diffusion from one site to another of social movements, tactics, frames, and symbols, and the notion of 'scale shift', which is part of the diffusion process. The link between coalition and diffusion/scale shifts highlights the coalition's potential as a 'transformative encounter' (Tsing, 2015) that produces or induces change; transforming, for instance, a local into a national or transnational protest, or providing an opportunity for learning and creative borrowing (see e.g. Rose, 2000, on interclass coalitions). This question is all the more central in authoritarian or constrained contexts such as those that predominate in the MENA region, where the idea that 'things change in order to remain the same' has replaced the spring metaphors of 2011 and 'the themes of failure and disappointment have been increasingly central to both media coverage and academic analysis of protest movements' (El Houri, 2018, p.72).

The contributions in this issue go beyond this idea of stability and continuity through change to focus on what Janine Clark (2012) calls 'slow change', meaning 'gradual social, economic and political changes at the local level' (p. 17). Illustrating how temporary coalitions contribute, for instance, to the emergence of new signifiers, set unprecedented agendas, alter local power hierarchies and trigger the creation of novel alliances, this special issue assesses the analytic opportunities that emerge when coalition moments are conceptualized as moments of transformation rather than as failed transitions to democracy.

We discuss these three points in more detail later in this introduction. First, however, we bring together the different aspects discussed in this section to formulate a working definition of the term 'coalition' as used by the different authors in this issue. Coalitions are collective action processes, limited in time and space, that bring together a wide range of actors or organizations who do not otherwise mobilize together but who mutually recognize one another and interact temporarily to share resources, frames, and information in their pursuit of a specific goal that is framed as a common cause.

\section{Research on Coalitions in North Africa and the Middle East}

Coalitions are widely found in the contemporary history of the MENA region (Chalcraft, 2016). However, research focusing on coalitions in relation to the emergence of protest actions and political alliances have appeared with increasing frequency in the 2000s. 
Since the broad-based uprisings in North Africa and the Middle East starting in 20102011, this interest has increased even more in the face of the cross-ideological, crossclass, and cross-regional coalitions that played a vital role in bringing about regime change in some cases, and reforms in others. This literature has three main characteristics: first, it focuses on ideological divides(e.g. leftists allying with Islamists); second, it sheds light on the formation of alliances in constrained authoritarian political contexts; finally, it analyses coalitions in relation to the question of democratization and/or regime change, focusing mainly on the factors that have made these alliances successful in achieving these objectives.

Research on coalitions in the MENA region has mainly focused on cross-ideological coalitions. For example, in her study on four different alliances between leftists, nationalists, and Islamists in Jordan, Janine Clark (2010) shows that cross-ideological coalitions represent the 'most important arenas of political activism in Jordan' (p. 102). Focusing on cooperation between leftist groups, nationalists, and the Muslim Brotherhood in Egypt in the early 2000s, Maha Abdelrahman (2009) identifies 'cooperative differentiation' (p. 39) as a fruitful tactic that enables coalitions of actors who have been enemies in the past to present a public face of solidarity while maintaining their internal differences. Such networking processes contributed to the broad-based uprisings in the region from 2010-2011 (Abdelrahman, 2011; Beinin, 2014). In their studies of these Arab uprisings Jack Goldstone (2010), Cilja Harder and Christoph König (2013), and Vincent Durac (2015) show how anti-regime social movements in several Arab countries grew stronger because coalitions formed between actors and organizations of very different ideological and social backgrounds. In particular, Michele Penner Angrist (2013) argues that one of the main factors of the emergence of cross-class and cross-regional mass demonstrations in Tunisia was the alliance between secularists and Islamists.

This body of research on cross-ideological coalitions has brought new insights into the making of alliances in constrained political regimes such as those that dominate in MENA societies. While Janine Clark's (2010) findings confirm existing studies focusing on nonauthoritarian regimes, they contrast with these studies when it comes to the issue of recruitment and resources: in Jordan, 'coalitions are more likely to fail under conditions of an abundance of available recruits', a factor that reinforces competition as well as actors' 'inability or unwillingness to work together' (p. 115). She also shows that, unlike 
in other contexts, coalitions in Jordan are mainly initiated in the context of external threats and less in the context of political opportunities. Comparing different Arab countries' trajectories during the uprisings of 2011, Cilja Harders and Christoph König (2013) highlight the importance of finding a 'consensus regarding the common objectives of the struggle' as 'a major asset to anti-regime coalitions challenged by various forms of repression' (p. 31). The alliance of youth movements with various ideological backgrounds within the Coalition of Revolutionary Youth in Egypt managed to contribute to regime change by focussing on street politics and adapting their strategies to the evolving political context (Abdalla, 2016).

Most authors highlight the fluid nature of coalitions in the MENA region, a factor that seems to be central to the formation of coalitions in constrained contexts. Janine Clark (2010) describes the coalitions that she studied in Jordan as 'weak' (p. 115), meaning that they did not involve the creation of a new umbrella organization. Ray Bush's (2011) study of a coalition challenging the impoverishment of Egypt's farmers shows the existence of fluid networks of resistance to rural dispossession in Egypt. Maha Abdelrahman (2009) describes the coalitions she has studied as loosely organized, showing fluid membership and an absence of clear leadership (p. 53). Vincent Durac (2015) also highlights the 'leaderless, horizontal, and largely non-ideological character' (p. 245) of the protest movements in 2011 as one of the factors that enabled the movements in Egypt and Tunisia to succeed in overthrowing their regimes.

In the early 2000 s this research focused on the link between coalitions and processes of democratization (Clark, 2010; Abdelrahman, 2009). After 2011, the focus moved towards regime change and the implementation of reforms concerning claimed human and social rights. During and immediately after the Arab Spring some argued that it was precisely because these protest movements were able to gather people beyond class divisions and ideological differences that they were, in some cases, able to overthrow regimes (Goldstone, 2011; Harders, König, 2013; Durac, 2015). In fact, Gianni Del Panta (2016) attributes the lack of a similar uprising in Algeria to the lack of a cross-class and crossideological coalition there.

During both the pre- and the post-Arab Spring phases, studying change in relation to coalition-building mainly meant studying the factors behind such coalitions' success or failure in their endeavours, whether these were democratization, regime change, or the 
implementation of reforms. Most authors conclude by highlighting the unsuccessful nature of these coalitions. According to Maha Abdelrahman (2009), the coalitions she has studied are beginning to use new forms of protest, but at the same time these are 'slow moving, reluctant and beset with major obstacles' (p. 53). In her conclusion, Janine Clark (2010) reminds the reader that 'the region's authoritarian regimes are still in place. Crossideological coalitions have achieved few of their policy goals, such as electoral law reforms' (p. 115). Analysing coalitions that formed during the uprisings of 2011, Vincent Durac (2015) and Jack Goldstone (2011) show that the diversity that characterized the actors involved contributed to their inability to sustain their coalitions after regime change. In a comparative analysis of the Arab uprisings, Steven Heydemann (2016) observes that 'building stable, legitimate, cross-cutting political coalitions' is very challenging and remains limited 'in the absence of broadly accepted rules of the game and viable state institutions and where non-state identities impede efforts to build political communities around widely shared conceptions of legitimacy and citizenship' (p. 199). We argue for the need to go beyond the question of whether coalitions in the MENA region are succeeding or failing in achieving their objectives, to take a closer look at the multiplicity of social and political transformations that can emerge out of coalition moments.

Building upon the rich insights of the existing literature on coalitions in the MENA region, in this issue we argue therefore that to better understand the making and unmaking of coalitions in the region it is important to examine them in greater detail. As we show there is a need for micro-sociological studies that are more attentive to the diversity of coalitions across various social divides, to the multiple transformations that can emerge from these moments of encounter, and to the close relation between coalition-building and fragmentation.

\section{The Diversity of Coalitions in North Africa and the Middle East}

In this special issue we show first that it is essential to consider a wide variety of social differences, including those based on class, gender, ethnicity, generation, and professional hierarchies. Before and after the Arab uprisings coalitions brought together a variety of social classes and social groups, bridging geographical boundaries and social divisions. Although they do not always analyse the formation of coalitions and the ensuing transformations in much detail, several recent publications indicate that thinking 
about collaboration across various social and political divides can inform us about the making of contentious politics.

Eric Gobe's (2017) work on the establishment of lawyers as collective actors in Tunisia shows, for instance, how the social segmentation and hierarchy within the profession shaped the alliance that emerged in 2011 between different generations of lawyers: young lower-level' and more established, politically-active lawyers. Sharon Erikson Nepstad's (2011) reflections on the critical role of alliances between the army and the opposition during the 2011 uprisings in Tunisia and Egypt indicate that more attention should be paid to these momentary collaborations. Arguing in favour of cross-ideological dialogue between Islamist and secular women's movements in Tunisia, Loes Debuysere (2016) shows that the polarization between the two is the result not only of ideological differences but also of class division, since 'secular women's associations are often led by upper- and middle-class women while religious-inspired associations tend to represent lower- and lower-middle-class women' (p. 227).

During the past two decades, coalition-building across social and geographical divides has been more particularly shaped by an increasing number of protest actions that have developed in the 'margins', meaning here both spaces and groups that are the historical product of processes of social and political exclusion, and/or economical dispossession and exploitation ${ }^{2}$. Against the backdrop of economic decline, rising food prices, intensified exploitation of resources and the dismantling of public services, protest actions led by small peasants (Ayeb, 2011; Bush, 2011), workers (Duboc, 2011), the urban poor, and small town citizens (Allal \& Bennafla, 2015; Bogaert, 2015) have recently gained in number. Most often, these protests take the form of 'heteroclite coalitions' (Allal \& Bennafla, 2015), ‘conjunctural alliances’ (Ayeb, 2011, p.467) or networks (Abdelrahmane, 2012; Bogaert, 2015) that cross social and geographical

\footnotetext{
${ }^{2}$ For a more detailed definition of 'margins' see Daniela Huber and Lorenzo Kamel's (2015) discussion of the role of peripheries during the Arab Spring.
} 
divides by bringing together marginalized populations and established elites, such as urban based lawyers and human rights activists for examples.

We argue that researchers' attention should be directed towards studying the ways in which compromises are negotiated between these different groups. For comparative purposes we need to keep in mind that coalitions are composed of a wide range of groups, with different goals and diverging views about how to achieve them. Internal differences will affect the type of coalition formed, its political leverage vis-à-vis the state, and its forms of action. While some groups or actors might have more focused objectives, such as the release of political prisoners or access to a specific public service or good (land, education, etc.), others may focus on deeper social and political reforms that require a shared vision of a given political project. How are these different objectives negotiated within a coalition, and how are common frames of action built? What emerges out of these negotiations? How do power hierarchies affect the formation of coalitions? And how is communication made possible between this wide variety of actors and organizations that are sometimes also geographically separate from each other?

In answer to these questions the contributors in this special issue analyse the formation of coalitions involving a variety of actors, such as the supporters of political Islam and liberal, nationalist and leftist groups protesting together against the Egyptian military regime's decision to sell two of its islands to Saudi Arabia (Jannis Grimm); professional labour-student coalitions in turn-of-the millennium Iran (Zep Kalb); the formation in Egypt of Kifaya, a coalition that developed at the intersection of ideological and generational divides in the early 2000s, and its evolution after the fall of Mubarak (Chaymaa Hasaboo); middle-class environmental activists and unemployed young men protesting together against the exploitation of shale gas in the Algerian Sahara (Naoual Belakhdar); and employees of a mining company in Jordan who joined forces beyond professional, corporate, tribal and local identity divides to voice their grievances about working conditions and governance in the company (Claudie Fioroni).

The authors contributing to this issue show that analysis of coalition-building at the intersection of various social divides enables the researcher to better grasp the internal dynamics that shape these alliances and to question common understandings of divisions within society. In her study of an atypical coalition within a Phosphate mine company in 
Jordan, Claudie Fioroni shows how this alliance that crossed categories of class, tribal identity, and generation, can be used to question the relevance of these categories, highlighting instead the importance of the political differences that emerged within the coalition. Interestingly, these differences do not necessarily overlap the above-mentioned categories that dominate Jordan's classical political sociology.

Internal differences also raise the issue of the temporality of the action of social movements in general and of coalitions in particular. Depending on the goals of the groups and actors that make up a coalition we can find different time scales with shortterm as well as long-term actions and objectives within the same coalition. It is the interplay of these conflicting temporalities that contributes to the making of coalitions, shaping expectations and conflicts. In a study of the coalition between a women rights organization and rural women claiming land rights in Morocco, Yasmine Berriane (2016) shows that tensions can emerge in coalitions when there are conflicting views on how quickly change should occur: while the women rights organization privileged a long-term strategy that fit the temporalities of (slow) institutional reform, the rural women, who faced an intensified commodification process, sought rapid solutions and territorial interventions in the short term. While the actors involved within the alliance were able to hide their internal differences behind their unified cause and terminology, they had a much harder time overcoming the tensions triggered by these conflicting temporalities.

A similar idea appears in Chaymaa Hasabo's contribution, in which she shows how intergenerational conflicts within Kifaya crystallized around the issue of diverging understandings of the pace that political change should be taking, with representatives of the Youth movement privileging more rapid measures than the older generation represented in the coalition. Similarly, in the anti-fracking coalition studied by Naoual Belakhdar in Ouargla, two distinct groups, a movement of unemployed youth and a loose network of middle-class environmental activists, differing both in their objectives and their class identities, joined forces. The author shows how class differences that crystallized around a lack of internal agreement on the long-term objectives of the coalition contributed to its collapse. While the environmental activists started asking for regime change, the unemployed people's movement refrained from taking sides in intraregime struggles. 
Complementarity seems to be one of the main reasons that leads to the production of coalitions in such conflictual contexts. Through their alliance, coalition partners bring together their different competences, knowledge and resources to achieve a common goal. Yet as mentioned, the construction of this common goal and of common frames remains a difficult and tricky moment in coalition-building. As the authors in this volume show, floating signifiers such as "the nation", "social justice" and "political change" can become unifying tools that convey powerful representations while at the same time remaining vague enough to enable each coalition partner to associate it with a different meaning, keeping the internal differences out of sight for a certain time. However, in all the cases presented in this volume divides that remained invisible during the first phase of coalition-building became the main reason for the end of the alliances when coalition members became increasingly aware of the differences that opposed their own concrete understanding of these goals and signifiers. This shows that studying the making of coalitions is also a way for scholars to study the making and reinvention of differences in society; a factor that is at the core of the second idea developed in this issue.

\section{Coalitions and social divides}

Rather than analysing coalitions and social divides as two opposite processes, we argue that studying the alliance of social groups and movements goes hand in hand with exploring processes of differentiation and categorization. We therefore include fragmentation in our study of coalitions, to understand how and under which circumstances actors come to experience social, economic and political categories as divisions that shape contentious politics. In other words, why are some coalitions considered 'unlikely' (Whittier, 2014)? What causes such divisions of socio-economic, and political space, and how are they overcome within coalitions? In what sense do coalitions contribute to reinventing, reshuffling or even reproducing such divides?

In the context of the political closure that characterizes authoritarian regimes, ideological differences are insufficient to explain the segmentation that hinders collaborative work between political groups, who often fall into the trap of essentialism or result in opposing different groups by taking these divisions for granted. Instead, we argue that fragmentation and social divisions are particularly salient as instruments of governance that influence the ways in which contentious issues are articulated. This raises the question of how coalitions form and function in such contexts, and how they affect 
regimes. A hypothesis that we consider worth verifying is that social movement coalitions represent a challenge to the regime's strategies and practice of 'divide and rule'. While their actions might not directly challenge the state, coalitions redefine the existing boundaries of collaboration between social and political groups by reinforcing differences or producing new ones. Building on these two points we stress the importance of situating coalitions within a long-term perspective that takes into consideration the role of the state, but also that of social actors in co-producing social and political divides.

Corporatism, for instance, is a form of societal segmentation that undermines the expression of class interests through co-optation. In the context of anticolonial struggle in the region, political elites promoted 'mass incorporation' into the political arena (Yousef, 2004). Labour groups are emblematic of such incorporation. In Tunisia the trade union movement, the UGTT, was close to the main nationalist political party, the NeoDestour. The Nasserist regime in Egypt also organized labour as an extension of the regime with the creation of the Egyptian Trade Union Federation (ETUF) in 1957. In this system economic and political rewards have been seen as 'aristocratic privileges' that prevent labour from playing a political role by encouraging trade union leaders to maintain an organic relationship with the state in order to ensure that their interests remain protected. Nationalization and distributive measures such as free education, food subsidies, health care, guaranteed jobs for university graduates, and agrarian reform have all been included in social and welfare policies underpinning a state-building project aiming to create support for emerging regimes.

This system of incorporation was extended to large segments of the population, which were organized into groups and associations - student and youth organizations, agricultural cooperatives, business groups - to hinder class conflict and make it more difficult for these groups to join forces against the regime. Zep Kalb's contribution focuses on the evolution of such corporatist strategies in the Middle East, using the example of Iran to illustrate how, via cross-class and cross-movement coalitions, corporatist associations can move from being instruments of rule to becoming, at least temporarily, (unruly) instruments of protest against governmental policies. Kalb shows more concretely how in reaction to different threats, the Workers House and the Student Union became coalition partners during the early years of 2000 in their protest against state policies. Although this alliance ended after 2003, it is indicative of the limits of 
authoritarian corporatism and triggered the emergence of new alliances and protest groups.

Thus, although social and political divides are rooted in long-lasting historical processes, they are open to change. Far from being a mark of the region's exceptionalism or a factor of enduring resistance to political transformation, political and social fragmentation is being challenged and reinvented, most notably through coalitions. This is also what Naoual Belakhdar shows in her contribution on protests against the Algerian government's fracking plans in Ouargla Province. The Popular Committee against Shale Gas cuts across the divisions inherited from the civil war and provides a case of crossclass and cross-regional cooperation, despite the regime's strategy to undermine its mobilization efforts by fragmentation, also known as 'cloning'; a strategy that involves infiltrating and co-opting groups to create competing organizations with the aim of weakening collaborative work. By enabling collaboration between actors from different regions, classes, and activist practices, the anti-fracking coalition challenged contentious political practices.

In a similar vein, Claudie Fioroni's study of labour action at the Jordan Phosphate Mines Company (JPMC) provides another example of a coalition challenging the 'divide and rule' strategies used by both the state and the mining company. Tribal, professional and corporatist divisions did not hinder the formation of a coalition between employees of the JPMC which cut across professional hierarchies from workers to engineers, social origins including northern middle-class citizens and southerners of Bedouin descent, educational backgrounds, and local and tribal identities. Instead, Fioroni's contribution shows that different understandings of social justice turned out to be relevant lines of divisions among employees of the JPMC.

Focusing on protests against the transfer of Egyptian islands to Saudi Arabia, Jannis Grimm analyses how they subverted the Egyptian regime's nationalist rhetoric by linking nationalism with revolution. Despite the fierce repression that followed the military coup in the summer of 2013 and the subsequent witch hunt for supporters of the Muslim Brotherhood, the transfer of these islands sparked a mobilization that transcended the regime's efforts to polarize the political space between 'nationalists' and 'Islamists', 'patriots' and 'traitors'. 
While these contributions explore how coalitions challenge regimes' divide-and-rule strategies by bridging social and political divides, they also illustrate how they simultaneously participate in producing or reinventing such divides. It was as a result of their interaction with older and more established civil society actors within Kifaya that the younger coalition partners studied by Chaymaa Hasabo realized that they needed to create their own movement, leading to the formation of the Youth for Change Movement. Naoual Belakhdar reports how internal hierarchies in the anti-fracking coalition in Algeria came to be experienced by members of the movement of the unemployed made class differences become a polarizing element that contributed to the deterioration of relations between coalition members. In her contribution Claudie Fioroni further shows that the making of a coalition through processes of association between different groups goes hand in hand with processes of dissociation that contribute to excluding those deemed to remain outside of the coalition. During this process new dividing lines can emerge such as the separation of "anti-establishment" and "pro-establishment" employees of the mining company.

\section{Coalition and change beyond the failure-success nexus}

Finally, this special issue goes beyond the failure/success nexus that dominates most of the literature on coalitions in North Africa and the Middle East. It suggests the following hypotheses: even when coalitions are only built on temporary and fragile alliances and fail to reach their goals, they set in motion diverse social and political (micro)transformations that are worth studying. This hypothesis builds on the idea that individuals and groups change through their collaboration; coalitions can therefore be seen as 'transformative encounters' (Tsing, 2015). The history of the MENA region shows that coalitions have left lasting impacts, despite failing to achieve their stated goals. For instance, in the early years of the twentieth century the armed struggles against European rule in the MENA region brought together under the banner of nationalism a wide range of constituencies that did not achieve their objectives of independence but fundamentally altered colonial rule: from direct to indirect rule in Iraq, and to the creation of state-like structures in Morocco following Abd Al-Krim's victory over colonial troops in 1921 (Chalcraft 2016, 303).

Our understanding of transformation does not imply any teleological and normative presupposition about the direction that these changes should be taking. To gain fresh 
understanding of the ongoing transformations in the MENA region, the authors of this special issue privilege a processual perspective that examines the multiple and often unpredictable and indeterminate reconfigurations and contradictions that constitute social and political change at the intersections of different scales. ${ }^{3}$ First of all, coalitions undergo different phases and transformations from their emergence to their potential decline or integration into the political system. As Jannis Grimm shows in his contribution on the 'Egypt is not for Sale' campaign, the aim of the coalition of different activist groups changed over time, from initially opposing the transfer of the islands to demanding the release of political prisoners, the revision of laws, and the deposition of corrupt government officials. Chaymaa Hassabo's article also traces different understandings of change among Egyptian activists during the emergence of the Kifaya coalition in the early 2000s and after the fall of Mubarak. Moreover, coalitions can lead to the emergence of new alliances, organizations and protest movements, as illustrated by all the contributions brought together in this volume. These new organizations have the potential to open up new spaces of action and new 'fields of possibility' (El Houri, 2018, p.76), as shown for instance by Maha Abdelrahman (2011) in her study of the alliance of anti-globalization activists in Egypt and the Global Justice Movement prior to the uprisings of 2011. The process of diffusion and brokerage that accompanied the networking between these domestic activists and transnational protest networks helped launch new projects for political transformation in Egypt.

Coalitions can also bring new political actors to prominence, such as bridge leaders, (Robnett, 1996) who enable the formation of coalitions across social divisions. Brokers play a central role in the formation of coalitions, developing and sustaining ties and facilitating interaction between different groups (Van Dyke and McCammon, 2010, xvixvii), reactivating 'existing relationships and ties (...) in conducive political contexts' (Corrigal \& Meyer, 2010, p. 8). Bridge builders contribute to 'explaining, justifying, and interpreting the coalition to peers, decision makers, and the public' (Rose, 2000, p. 187). In this central role they may enrich and broaden their networks and become more visible within the public sphere (Berriane, 2016), and acquire new competencies and knowledge that enable them to continue their action as parliamentarians (see Fioroni in this volume),

\footnotetext{
${ }^{3}$ Similar to the approach advocated by Steven Heydemann (2016) in his comparative analysis of transformations that emerged from the Arab uprisings.
} 
making them aware of their importance as key social actors able to mobilize the masses (see Belakhdar in this volume).

Within an alliance the interplay between the diverse repertoires, skills, and frames that different groups employ to support their aims also contributes to the diffusion and exchange of repertoires of actions. Alliances can further lead to the emergence of new frames of reference or signifiers and to the diffusion of goals, causes, and ideas such as the hegemonic discourse on 'tunisianite' that 'served as a unifying idea to bridge opposing views on who or what constitutes the people' in the coalition that formed across various social divides in Tunisia in 2010-2011 (Zemni, 2016, p. 133). Similarly, Jannis Grimm shows how the campaign led by the Egypt is not for Sale coalition subverted hegemonic discourses about the nation that maintained the status quo by dislocating and reinventing the nationalist rhetoric to which the regime had tied its legitimacy. By combining references to national unity and sovereignty with principles of social justice and scientific arguments provided by environmental activists who belong to Algeria's established elite with the street credibility provided by the unemployed youth movement, the coalition that Naoual Belakhdar studied gave credibility to the cause of anti-fracking while contributing to changing the image of marginalized actors in a peripheral region of Algeria. In Egypt, references to "political change" and "reform" enabled Kifaya's coalition partners to bridge their ideological and generational differences, but through their interactions within the coalition the different groups became aware of their diverging understandings of change and reform. Thus within the same cross-ideological and crossgenerational coalition, different ways of thinking about and acting for political change met, leading to a reconceptualization of these actors' understanding of political change.

\section{Conclusion}

Through studies of the formation of alliances across social divides, this special issue considers contentious politics in the MENA from the vantage point of mobilizations that are often considered anecdotal, episodic, or marginal. The articles study coalitions whose activity takes place mainly in capital cities with the participation of actors or groups from regions or social backgrounds considered to be on the margins of contentious action. This marginalization is perhaps most apparent in the wake of the Arab uprisings, with protests in city squares seen as the epicentre of street politics. 
Regardless of their regional location or their participants' geographical or social origin, the ebb and flow of the alliances presented in this issue lead to short-term action. They all end with the demobilization of their constituents. The coalitions' short-term temporality takes us back to the definition of social movements. Because they fall short of creating a collective identity, alliances form around a shared cause, during a campaign for instance, without leading to sustainable movement-building. This gives coalitions a peculiar position at the margin of social movements, which are defined as sustained action that involves the formation of collective identity (Tarrow \& Tilly, 2007, p. 8).

While engaging with this dimension all of the contributions include discussion of the coalitions beyond their limited lifetimes to understand their micro dynamics. The approach here is three-fold: first it focuses on the diversity of coalitions, considering alliances that bring together actors across class, ethnic, generational, and even professional divisions. Second, the contributions go beyond analysis of their success or failure to reflect on the context that contributed to the formation of such diverse alliances and to understand their transformative power. Finally, the authors show how the state of contention is highly influenced by the segmentation that authoritarian regimes implement to undermine the formation of cohesive opposition movements. Far from being immutable, this fragmentation is subverted and reinvented by the formation of coalitions. 


\section{References}

Allal, A., \& Bennafla, K. (2011). Les Mouvements Protestataires De Gafsa (Tunisie) et Sidi Ifni (Maroc). De 2005 à 2009. Revue Tiers Monde, 5, 27-45.

Abdalla, N. (2016). Youth Movements in the Egyptian Transformation: Strategies and Repertoires of Political Participation. Mediterranean Politics, 21(1), 44-63.

Abdelrahman, M. (2009). 'With the Islamists?-Sometimes. With the State?-Never!' Cooperation between the Left and Islamists in Egypt. British Journal of Middle Eastern Studies, 36(1), 37-54.

Abdelrahman, M. (2011). The Transnational and the Local: Egyptian Activists and Transnational Protest Networks. British Journal of Middle Eastern Studies, 38(3), $407-24$.

Abdelrahman, M. (2012). A Hierarchy of Struggles? The 'Economic' and the 'Political' in Egypt's revolution. Review of African Political Economy, 39(134), 614-628.

Angrist, M. P. (2013). Understanding the Success of Mass Civic Protest in Tunisia. The Middle East Journal, 67(4), 547-564.

Ayeb, H. (2011). Social and Political Geography of the Tunisian Revolution: The Alfa Grass Revolution. Review of African Political Economy, 38(129), 467-479.

Barakat, H. (1993). The Arab World: Society, Culture, and State. Berkeley: University of California Press.

Beinin, J. (2014). Civil Society, NGOs, and Egypt's 2011 Popular Uprising. South Atlantic Quarterly, 113(2), 396-406.

Berriane, Y. (2016). Bridging Social Divides: Leadership and the Making of an Alliance for Women's Land-Use Rights in Morocco. Review of African Political Economy, 43(149), 350-364.

Bogaert, K. (2015). The Revolt of Small Towns: The of Morocco's History and the Geography of Social Protests. Review of African Political Economy, 42(143), 124140. 
Bush, R. (2011). Coalitions for Dispossession and Networks of Resistance? Land, Politics and Agrarian Reform in Egypt. British Journal of Middle Eastern Studies, 38(3), $391-405$.

Butler, J. (2016). Vulnerability, Precarity, Coalition. In D. Gardey \& C. Kraus (Eds.), Politics of Coalition: Thinking Collective Action (pp. 251-271). Zurich/Geneva: Seismo.

Chalcraft, J. ( 2016). Popular politics in the making of the modern Middle East. Cambridge: Cambridge University Press.

Clark, J. (2010). Threats, Structures, and Resources: Cross-Ideological Coalition Building in Jordan. Comparative Politics, 43(1), 101-120.

Clark, J. (2012). A Call for the Quotidian, the Local, the Peripheries and a Spatial Dimension. Arab Uprisings. New Opportunities for Political Science, POMEPS Briefings 12, June, 17-19.

Cornfield, D., \& McCammon, H. (2010). Approaching Merger: The Converging Public Policy Agendas of the AFL and CIO, 1938-1955. In N. Van Dyke \& H. J. McCammon (Eds), Strategic Alliances: Coalition Building and Social Movements (pp. 79-98). Minneapolis/London: University of Minnesota Press.

Corrigall-Brown, C., \& Meyer, D. S. (2010). The Prehistory of a Coalition: The Role of Social Ties in Win without War. In N. Van Dyke \& H. J. McCammon (Eds.), Strategic Alliances: Coalition Building and Social Movements (pp. 3-21). Minneapolis/London: University of Minnesota Press.

Davis, E. (2008). Pensée 3: A Sectarian Middle East? International Journal of Middle East Studies, 40(4), 555-58.

Debuysere, L. (2016). Tunisian Women at the Crossroads: Antagonism and Agonism between Secular and Islamist Women's Rights Movements in Tunisia. Mediterranean Politics, 21(2), 226-245. 
Diani, M. (2006). Networks and Participation. In D. A. Snow, S. A. Soule, \& H. Kriesi (Eds.), The Blackwell Companion to Social Movements (pp. 339-359). Oxford: Blackwell.

Diani, M., \& Bison, I. (2004). Organizations, Coalitions, and Movements. Theory and Society, 33(3/4), 281-309.

Diani, M., \& McAdam, D. (2003). Social Movements and Networks: Relational Approaches to Collective Action. Oxford: Oxford University Press.

Durac, V. (2015). Social Movements, Protest Movements and Cross Ideological Coalitions: The Arab Uprisings Re-appraised. Democratization, 22(2), 239-258.

Duboc, M. (2011). La contestation sociale en Egypte depuis 2004. Précarisation et mobilisation locale des ouvriers de l'industrie du textile. Revue Tiers Monde, 5, 95-115.

El Houri, W. (2018). Beyond Failure and Success: Revolutions and the Politics of Endurance. Radical Philosophy, 2(02), 72-78.Gobe, E. (2017). Lawyers Mobilizing in the Tunisian Uprising: A Matter of 'Generations'? In M M. Ayyash \& R. Hadj-Moussa (Eds.), Protests and Generations: Legacies and Emergences in the Middle East, North Africa and the Mediterranean (pp. 73-95). Leiden: Brill.

Goldstone, J. A. (2011). Cross-Class Coalitions and the Making of the Arab Revolts of 2011. Swiss Political Science Review, 17(4), 457-62.

Haddad, F. (2014). A Sectarian Awakening: Reinventing Sunni Identity in Iraq After 2003. Current Trends in Islamist Ideology, 17, 145-176.

Harders, C., \& König, Ch. J. (2013). Mobilization, Repression, and Coalitions: Understanding the Dynamics of the Arab Spring. Discussion Paper, February, Center for Middle Eastern and North African Politics, Free University, Berlin.

Heydemann, S. (2016). Explaining the Arab Uprisings: Transformations in Comparative Perspective. Mediterranean Politics, 21(1), 192-204. 
Huber, D., \& Kamel, L. (2015). Arab Spring. The Role of the Peripheries. Mediterranean Politics, 20(2), 127-141.

Lacher, W. (2016). Libya's Local Elites and the Politics of Alliance Building. Mediterranean Politics, 21(1), 64-85.

Lemieux, V. (1997). Réseaux et coalitions. L’Année Sociologique, 47(1), 55-71.

Makdisi, U. (2000). The Culture of Sectarianism. Community, History, and Violence in Nineteenth-Century Ottoman Lebanon. Berkeley and Los Angeles: University of California Press.

Meyer, D. S., \& Whittier, N. (1994). Social Movement Spillover. Social Problems, 41, $277-298$.

Nepstad Sh. E. (2011). Nonviolent Resistance in the Arab Spring: The Critical Role of Military-Opposition Alliances. Swiss Political Science Review, 17(4), 485-491.

Del Panta, G. (2017). Weathering the Storm: Why was there no Arab Uprising in Algeria? Democratization, 24(6), 1085-1102.

Robnett, B. (1996). African-American Women in the Civil Rights Movement, 19541965: Gender, Leadership, and Micromobilization. American Journal of Sociology, 101(6), 1661-1693.

Rose, F. (2000). Coalitions across the Class Divide: Lessons from the Labor, Peace, and Environmental Movements. Ithaca, N.Y.: Cornell University Press..

Roth, B. (2010). Organising One's Own as Good Politics: Second Wave Feminists and the Meaning of Coalition. In N. Van Dyke \& H. J. McCammon (Eds.), Strategic Alliances: Coalition Building and Social Movements (pp.99-118). Minneapolis/London: University of Minnesota Press.

Rucht, D. Movement Allies, Adversaries, and Third Parties. (2004). In D. A. Snow, S. A. Soule, \& H. Kriesi (Eds.), The Blackwell Companion to Social Movements (pp. 197-216). Oxford: Blackwell. 
Shaffer, M. B. (2000). Coalition Work among Environmental Groups. In P. Coy (Ed.), Research in Social Movements, Conflicts and Change (Vol. 22, pp. 111-126). Emerald Group Publishing Limited.

Staggenborg, S. (1986). Coalition Work in the Pro-Choice Movement: Organizational and Environmental Opportunities and Obstacles. Social Problems, 33, 374-90.

Tarrow, S.G. (2011). Power in Movement: Social Movements, Collective Action, and Politics. Cambridge Studies in Comparative Politics. Cambridge: Cambridge University Press.

Tilly, C., \& Tarrow, S. (2007). Contentious Politics. Boulder: Paradigm Publishers.

Tsing, A. L. (2015). The Mushroom at the End of the World: On the Possibility of Life in Capitalist Ruins. Princeton: Princeton University Press.

Van Dyke, N., \& McCammon, H. J. (2010). Introduction: Social Movement Coalition Formation. In N. Van Dyke \& H. J. McCammon (Eds.), Strategic Alliances: Coalition Building and Social Movements (xi-xxviii). Minneapolis/London: University of Minnesota Press.

Whittier, N. (2014). Rethinking Coalitions: Anti-Pornography Feminists, Conservatives, and Relationships between Collaborative Adversarial Movements. Social Problems, 61(2), 175-193.

Yousef, T. M. (2004). Development, Growth and Policy Reform in the Middle East and North Africa since 1950. Journal of Economic Perspectives 18(3), 91-115.

Zemni, S. (2016). From Revolution to Tunisianité. Who is the Tunisian People? Creating Hegemony through Compromise. Middle East Law and Governance 8, 131-150. 